\title{
A SPREADSHEET PROGRAM (SCALLOPEX) TO CALCULATE PALEOVELOCITIES FROM CAVE WALL SCALLOPS
}

\section{RAČUNANJE PALEOHITROSTI KRAŠKIH TOKOV NA OSNOVI ANALIZE FASET NA JAMSKIH STENAH S PROGRAMOM SCALLOPEX}

\author{
Emily WOODWARD ${ }^{1} \&$ Ira D. SASOWSKY ${ }^{1}$
}

\begin{abstract}
UDC 911.2:551.435.8

Emily Woodward \& Ira D. Sasowsky: A spreadsheet program (ScallopEx) to calculate paleovelocities from cave wall scallops

The determination of paleovelocities through analysis of scallops on cave walls is an important part of paleohydrologic analysis. The linked equations that must be solved to do this are cumbersome, though. This paper presents a spreadsheet program that simplifies the process. The user enters scallop lengths, paleotemperatures, and passage dimensions; and the program returns velocities.

Keywords: paleohydrology, scallops, dissolution, velocity.
\end{abstract}

Izvleček

UDK 911.2:551.435.8

Emily Woodward \& Ira D. Sasowsky: Računanje paleohitrosti kraških tokov na osnovi analize faset na jamskih stenah $s$ programom ScallopEx

Geometrija faset $v$ jamskih rovih je odvisna od hitrosti in smeri vodnega toka. Preko analize faset $\mathrm{v}$ starih neaktivnih rovih, lahko torej sklepamo o hitrosti in smeri toka $\mathrm{v}$ času, ko so bili rovi še aktivni. Ker pa imamo opraviti s precej okornimi enačbami, smo razvili enostaven preglednični program, ki nam pri tem pomaga. Uporabnik vnese dolžino faset, paleotemperaturo in dimenzijo jamskega rova, program pa kot rešitev vrne hitrosti. Ključne besede: paleohidrologija, fasete, raztapljanje, hitrost toka.

\section{INTRODUCTION}

Meteoric limestone caves form by water flowing through carbonate rocks, but in many cases that water is no longer present when the cave is studied - the cave is dry and hydrologically abandoned. Therefore, the researcher seeking to decipher the genesis of the cave, or its context in the landscape, must use indirect methods to understand the paleohydrology. One of the most exciting and useful discoveries in this field was the recognition that the size of a cave wall scallop (also called current marking, Fig. 1) is dependent upon the speed and direction of the water that formed the features (Bock 1913; Coleman 1945). Based on morphology one can determine paleoflow directions - the steep face of the scallop faces the downstream direction. By measuring the scallop lengths one may then calculate paleovelocities (method of Curl 1974). Finally, one can identify a suitable segment of cave passage, measure the cross-sectional area, and then calculate a paleodischarge through the conduit by taking the product of the paleovelocity and the passage cross-sectional area. Detailed examples and explanations are given by Palmer (2007), including caveats on the application of the method.

The relation between flow velocities and scallop length relies on parameters such as water viscosity and density (both temperature dependent), and the dimensions of the conduit. These affect the Reynolds number (Curl 1974).

\footnotetext{
${ }^{1}$ Office for Terrestrial Records of Environmental Change, Dept. of Geology and Environmental Science, University of Akron, Akron, Ohio 44325-4101 USA, e-mail: eew6@zips.uakron.edu, ids@uakron.edu
} 


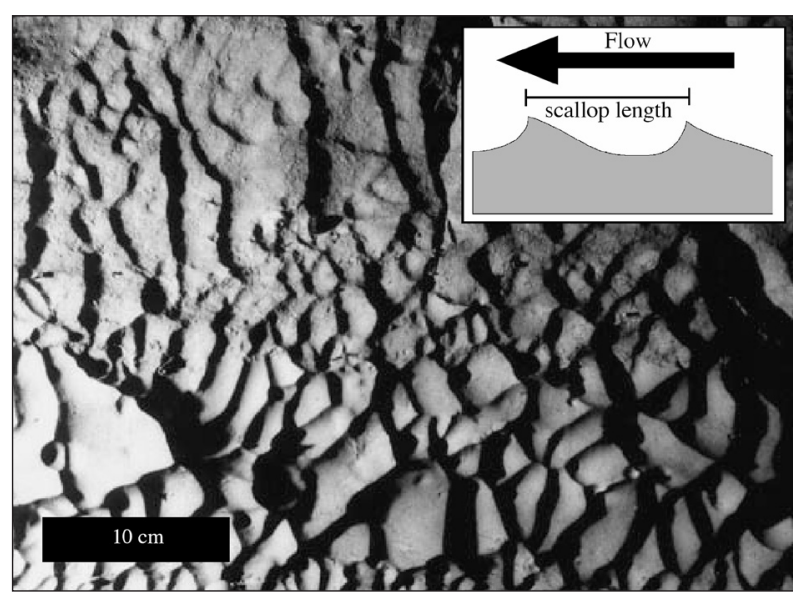

Fig. 1: Photograph of wall scallops from Mountain Eye Cave, Tennessee. Inset shows relation between fluid flow and scallop morphology (Photo: I. Sasowsky).

As a result, the calculation, although not complex, is cumbersome. We developed a spreadsheet (ScallopEx) that implements Curl's (1974) relationship between scallop size and velocity in order to facilitate this calculation. The user enters a series of scallop lengths, along with passage diameter, and the program then calculates paleovelocity (Fig. 2). Default conditions are full conduit flow, and a temperature of $13^{\circ} \mathrm{C}$. The user may modify these if desired. The program was developed in Microsoft Excel 2003 (Windows platform). Native Excel functions (not Visual Basic) are used, and the file is operable in the MacOS as well as Windows operating systems. We validated the ScallopEx results against hand-calculated datasets from Zinz (2006) as well as graphs provided in a textbook (White 1988, p. 100). In both cases there was agreement.

The spreadsheet may be useful for research calculations, and also for a teaching/lab experiences. It can be used to visually explore, through the graphing capability of Excel, the sensitivity of the velocity/scallop length relationship to changes in passage dimensions, temperature, etc. For example, Fig. 3

Fig. 2: Screen capture of the Excel file. 

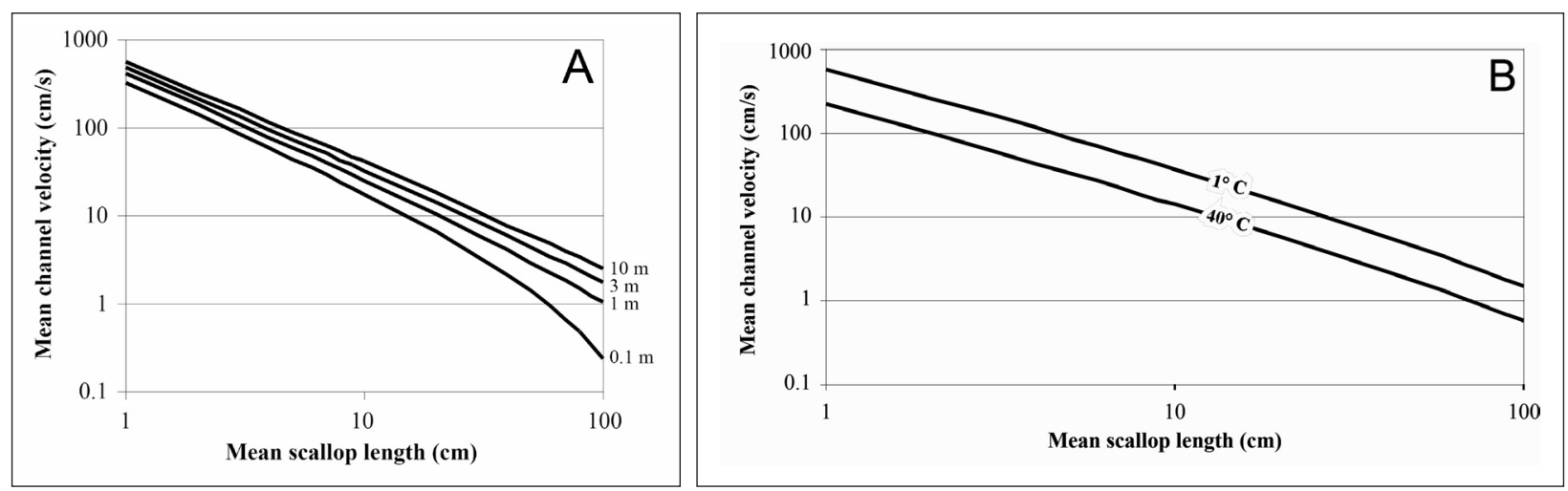

Fig. 3: Evaluation of the effect of $(A)$ conduit diameter and (B) temperature on paleovelocity calculation. All cases are for round conduits.

shows the effects of varying diameter and temperature on the calculation.

ScallopEx is available at http://www.uakron.edu/ geology/facpages/ids/downloads/scallopex.zip as a ZIP archive. The user will need to have a compatible version of Excel or other software in order to run it.

\section{REFERENCES}

Bock, H., 1913: Der karst und seine gewasser.- Mitteilungen für Höhlenkunde, 6, unpaginated.

Coleman, J.C., 1945: An indicator of waterflow in caves.Geological Magazine, 82, 138-139.

Curl, R.L., 1974: Deducing flow velocity in cave conduits from scallops.- National Speleological Society Bulletin, 36, 2, 1-5.

Palmer, A. N., 2007: Cave Geology.- Cave Books, p. 454, Dayton, Ohio.
White, W. B., 1988: Geomorphology and hydrology of karst terrains.- Oxford University Press, p. 464.

Zinz, D., 2006: Structural and hydrological influences on the evolution of Hellhole Cave, Pendleton County, West Virginia.- M.S. Thesis, University of Akron, pp. 89. 